\title{
The Function of the Church in Industry
}

\author{
By Rev. Harry F. Ward \\ Secretary, The Methodist Federation for Social Service
}

$\mathrm{I}_{\mathrm{P}}^{\mathrm{N}}$ relation to industry the Church performs a threefold function:

It is the teacher of the principles of conduct;

It is the voice of moral judgment;

It is the herald of a new order.

Whatever form the Church takes, it always fulfills in some degree this threefold function, save for those temporary groupings whose members vainly seek to evade the difficulties of this present life by turning their eyes constantly toward a future state of their own imagining.

In this discussion the term "industry" means something more than organized manufacturing. Because of the well-nigh universal presence and influence of the machine, industry now means all those relationships of economic activity which are both the essentials of human existence and the means to culture. This coal and iron age has given these relationships so large a place in life that the religious organization which ignores or neglects them will engage men for but an aesthetic interlude in more urgent affairs or for a fleeting moment as they make their exit from this world.

In the teachings concerning the way of life which the Church has undertaken to spread throughout the world, there are to be found three fundamental principles of social organization; the supremacy of personality, the necessity of brotherhood, the obligation of service. These principles have emerged in the long social experience of mankind. They represent struggle and achievement as well as hope and faith. They have been paid for with a great price. Upon them religion sets its sanction, declaring them to represent the nature and purpose of God, asserting that by them man must live if he would have fellowship with the Eternal.

These principles are generally accepted among us. To them most men render lip service, if nothing more. Yet it is notorious that they do not control the industrial order, whose basic principles of organization are the supremacy of property, the necessity of self-interest and the obligation of profit, so that personality, brotherhood, and service have continually to struggle for their life. This conflict between Christian teaching and industrial practice is straining modern life to the breaking point, because it is at bottom a contest between the forces of life and the germs of decay for control of the body politic. Industrial civilization, just growing into self-consciousness, is now choosing to which of these two sets of principles it will entrust the dominance of its collective life. Which shall be master and which servant? As history demonstrates, it is the choice between the way of life and the way of death for organized humanity.

In such a pass, in what grouping of its varied life shall mankind learn what principles of conduct make for a continuing social order? In the Statefrom the voices of officeholders touched of necessity with the infirmity of opportunism? In industry-from captains of finance or leaders of labor caught in the toils of a warfare of sectional interests? In science-from economists, sociologists, technicians, trained as specialists in one field of research, one segment of life? To each of these his task, and from each his 
contribution, but to the Church falls the duty of coördinating the capacities and achievements of all these fellowworkers, of adding to this common counsel the sanction and the dynamic which come only when men contemplate their duty and the possibilities of mankind sub specie aeternitatis and also sub specie communitatis.

\section{The Obuective of the Church}

As the Church attempts to get translated into terms of organized life principles which are generally accepted as desirable, it becomes evident that its educational objective is twofold. It seeks to get people who live in a world where points of views are continually determined by property, self-interest and profit, to take their attitudes and form their judgments in terms of personality, brotherhood and service. It also seeks to get people to express these principles in concrete acts, measures and policies. The former is mainly the task of the pulpit, the latter of the discussion group. It is the preaching function of the Church, both in individual and collective utterance, to show men what industrial life means and ought to mean, by lifting them out of the narrow interests and temporary conflicts of the moment into the larger atmosphere of universal and abiding principles. It is through the other teaching agencies of the Church, in discussion groups in which people of varied training and interests participate, that agreement may be reached as to what concrete acts, measures and policies sufficiently express the principles of Christian teaching to require for them the support of church members as a religious duty.

This is the way in which the churches have been proceeding. The growing body of educational material which they have put out in this field, and the statements adopted by various eccle- siastical bodies, both formulate general standards of industrial action as present expressions of the basic principles of Christianity and also specify certain measures which are to be supported as more or less satisfactory expressions of these standards. For example, practically all church authorities have declared that the Christian concept of the nature and worth of personality demands that the first charge upon any industrial undertaking is the adequate support of those actually engaged in it, and urge their constituents to work in various ways for a living wage as a minimum. In like manner, they insist that the necessity of brotherhood be applied to the distribution of wealth. They ask what economic necessity requires luxury to continue to increase and capital to multiply, while wages are being cut and the standard of living lowered for large numbers of people? Similarly these church utterances point out that when Christians talk of the obligation to service, they must ask what this means in terms of an industrial order that relies for its efficiency upon the profit motive; they must discover what it requires, for example, in the matter of access to natural resources and raw materials by different classes, nations and races.

The increase of preaching and discussion concerning the meaning of Christianity in terms of the industrial order should stimulate experiment on the part of those bearing industrial responsibility. If religion is sociallyminded, it will continually stimulate adventurous spirits to creative enterprise in the vast laboratory of economic organization. At this point, the Church has a definite responsibility as a church. Practically all religious organizations are in business in various ways-as employer and investor, as manufacturer (of printing), and landlord. What better way to teach the 
meaning of Christian principles than to demonstrate them? Yet in modern industrial history, I am not aware of a single case in which church management has set new standards. So far, the experimenting has been done in socalled secular business enterprise and church organizations have been but followers, and often limping, tardy followers at that.

\section{Ethical Standards}

In the process of teaching an industrial society the present meaning of those principles of conduct and association which have been developed in the experience and approved by the desires of the past, the Church inevitably becomes the voice of moral authority. It constantly finds itself compelled to pass judgment on situations and programs, on movements and systems; to indicate whether or not, and to what degree, they embody and exemplify the principles of its teaching. If it avoid this often disagreeable duty, no matter how sonorous its proclamation of essential principles, it becomes but a blind leader of the blind, heading for the ditch that finally receives those who mouth sound principles while they continue or sanction contradictory practices.

In practice the voice of the Church in industrial matters is expressed by individual men on their own responsibility, as for instance, the writings of such men as Rauschenbusch or Ryan; or by representative groups, either clerical or both clerical and lay, as for instance, the Catholic Bishops' Program of Reconstruction, or the Steel Strike Report of the Interchurch World Movement; or by the formal action of official, ecclesiastical bodies, as for instance, the famous encyclical of Pope Leo XIII "On the Condition of Labor," or the various statements adopted by Protestant denominations. Running through all these utterances, there is a common voice. They agree in their condemnation of certain general practices of the industrial world and of certain elements in its accepted social philosophy, as being anti-social and therefore irreligious. This very fact establishes a moral judgment of sufficient social validity that it cannot with impunity be disregarded by our industrial civilization.

Yet the right of the Church to utter moral judgments concerning industrial issues is now being vigorously contested by those whose industrial conduct has heretofore been without restraint of any authority. In final analysis, this is the question of the authority of the pulpit and the clergy, because the voice of the Church in these matters, while it may at times be formed with the participation of some laymen, and at times uttered with the approval of even more, will necessarily be formulated and uttered for the most part by those set apart for that purpose. Because this voice does and will often run counter to accepted practices and views, it will necessarily meet the opposition and even the rebellion of a considerable section of the laity. On what basis then can the pulpit, individually and collectively, establish a moral authority which society evidently needs?

\section{The Authority of the Churci}

If the voice of the Church is to have authority over the conscience and actions of men and the ways of society, that authority must be inherent in its judgments. To the degree in which they are characterized by appeal to enduring values, by competent handling of facts, and by disregard of consequences to those uttering them, they will have power. The world may resist for a while the vision of the prophet, reject for a time the counsel of knowl- 
edge, trample under foot for a day the devotion of the martyr, but finally it must needs follow them.

So the right of the clergy to utter judgment concerning industry rests upon and will be maintained by the strength and integrity of their conviction that they speak the enduring word, upon their proven competency to handle the facts and forces of the industrial world, and upon their willingness to risk discomfort and loss both for themselves and their Church. These conditions are to some degree being met. In recent years, the churches are training a group of men in the historical knowledge of both the social experience and the religious convictions of the race and in such acquaintance with industrialism that their utterances cannot be waved aside as the voice of zeal without knowledge. Furthermore, they are teaching more men how to use for purposes of moral judgment the work of specialists in industrial investigation and research. It is significant that none of the findings of church bodies concerning recent industrial conflicts have been successfully disputed as to statements of fact. Some of these findings, as in the matter of the steel strike and the open shop campaign, have cost church bodies something in the loss of funds. Such a process of judgment, thus demonstrating its intellectual competence and its moral validity, cannot be deprived of authority. This authority will increase in a democratic age to the degree that the voice of the clergy is characterized by a sympathetic sense of a common responsibility for the situations in which judgment is uttered. Only those who feel deeply the bondage of the common body of this death in which the industrial system has tied us all, can help mankind to escape from it and to find the way of life.

In the clash of conflicting interests the judgment of the Church acquires also the authority of some degree of detachment. Speaking generally, the living of the Church comes from all parties to the industrial conflict. Like the impartial chairman in some industrial boards who is paid by both sides, it need be swayed by neither. Yet its highest allegiance is not to both, but to the common social welfare alone. It is partisan only to the facts and to humanity. In the present condition of universal industrial belligerency only the man of science and the man of religion can reach this degree of detachment, and these not without effort. They must, therefore, join forces to maintain the authority of the common weal as they see it. It is the nearest we can come to any disinterested guidance for humanity.

The function of the Church in relation to industry does not end with teaching principles and uttering judgments. It is the organization that seeks the realization of the ideal and its expression in life. It stands for what ought to be and therefore continually turns the eyes and the steps of men toward a better way of living. It is and always will be the herald of a new order. Its supreme task is to arouse the faith and hope, to generate the love, that will continually create improved forms of social organization.

To most beneficiaries of the established order this aspect of the function of the Church is particularly objectionable. To them it is sacrilege even to suggest the temporary nature of capitalism. But the teachers of religion know that the steel and concrete in which the industrial order has encased life are no more permanent than wood and clay, stocks and bonds than crowns and thrones, and they must declare their knowledge. Moreover, the hour impels. Already there is a deep and wide revolt of the spirit of man against 
the present industrial order for its inhumanity, its injustice, its belligerency, its inefficiency. This rebellion affects the constitution of the universe, for it affirms that if this tragic disorder which we call civilization be the climax of human effort, then is the social struggle of mankind but a cosmic jest. In such a time, it becomes the duty of organized religion to prevent, if it may, the ruling groups from obstructing the highway of progress and the repressed groups from tearing up the road.

Thus many present voices of the Church call men to the creative task of developing a new order, whether it be a sect declaring that in the ideal society all property with the exception of such things as are necessary for personal and household use should be owned communally, or whether it be
Methodists saying that industry must be transferred from the basis of gain to the basis of service, or Catholics insisting that capitalism and socialism are alike unchristian and must be replaced by a system of individual, coöperative ownership. It is the distinction of these modern religious voices that they do not call men to make a fixed pattern for society. They have caught the scientific method. They do not pretend to know what we shall be, but they urge men constantly to use both reason and faith to discover new ways of living more in harmony with our ideals and with the results of experience. They challenge the creative energy of man to unite with the creative spirit of the universe in continually developing the capacities of humanity for living together. 